\title{
COMPARATIVE STUDY OF METHANE PRODUCTION FROM GROUNDNUT STRAW, BAMBARANUT STRAW AND MILKWEED PLANT
}

\author{
Awulu J.O, Omale P.A, Wonov T.J \\ Department Of Agricultural And Environmental Engineering, \\ University Of Agriculture Makurdi, Benue State, Nigeria
}

\begin{abstract}
A comparative analysis of methane yield from Bambaranut Straw, Groundnut Straw and milkweed Plant substrate was experimented using 30 litres batch digesters constructed from mechanical workshop, University of Agriculture Makurdi for the research work. Three replicates of $10 \mathrm{~kg}, 8 \mathrm{~kg}$ and $6 \mathrm{~kg}$ for each substrate were digested for 30days of retention period. Water was heated at $25^{\circ} \mathrm{C}$ and added as a startup heat after loading. Temperature variation in the digester was measured using a thermometer and $\mathrm{pH}$ (ranged 5.0 - 7.0) was measured using the $\mathrm{pH}$ meter. Anaerobic digestion of the substrate of Bambaranut Straw yielded less compared to groundnut straw and milkweed plant yielded more. The bambaranut straw yielded less because of the much acidic level. Analysis of variance (ANOVA) revealed that there's no significant difference between the $10 \mathrm{~kg}$ and $8 \mathrm{~kg}$ while there is significant difference at $6 \mathrm{~kg}$ for the substrates used.
\end{abstract}

Keywords: Methane, Bambaranut, Groundnut, Milkweed Substrate, Water.

\section{INTRODUCTION}

The big challenge of modern life as regard energy supply is the search for technology that will allow for more efficient and less cost effective way of producing energy, one technology that can successfully solve this world problem is anaerobic digestion (AD) (1). Agricultural waste have a large potential as an energy source, the increase in agricultural activities resulting to increased agricultural waste and the expansion of the renewable energy sector shows that agricultural wastes could play a vital role in the future of biofuels sources.

Renewable energy has remained one of the best alternative ways for sustainable energy development, especially for the rural and suburban areas. As fossils fuels become scarce and more expensive and carbon dioxide emission levels becomes of greater concern, the benefits and potential of biogas as a source of energy supply are being increasingly recognized (2). Biogas is methane rich gas produced from the anaerobic digestion of organic materials such as agricultural waste and biodegradable materials, biogas is produced when biomass is subjected to biological gasification (3). Methane is the major components of the biogas used in many homes for cooking and heating. It is odorless and colorless. Organic substances such as human, animal and agricultural waste can be digested under anaerobic to produce gas and sludgy used as fertilizer (4).

The production of methane is achieve effectively when factors such as $\mathrm{pH}$ value of the slurry in the digester is duely considered, the $\mathrm{pH}$ value of the slurry in the digester is an important indicator of methane organic performance. Gas is produced if the $\mathrm{pH}$ value of the substrate is between 6.6 and 7.6. Gas production is highest when the $\mathrm{pH}$ is between 7.0 and 7.2 (5). Beyond this $\mathrm{pH}$ limits, digestion can precede but with less efficiency as the loading rate of the substrate depending on the type of digester use affect the $\mathrm{pH}$ values which in turn result to rapid production of volatile acid with the resultant inhibition of the organic materials. It may also occur as a result of temporary presence of inhibitors and toxicants. Fluctuation in $\mathrm{pH}$ can be accommodated through proper control of temperature/loading rate and adequate mixing, however, effective and tight control of $\mathrm{pH}$ requires the availability of sufficient alkalinity to form buffer in the system. 
Due to the increasing rate of power failure in the country, both in houses, production factories which has resulted to low yield in economic standard as well as global warming of atmospheric condition which is caused as a result of excess carbon dioxide from fossil fuels therefore the need for renewable energy is called for in other to help in solving the current energy challenges in both urban and suburban environments by focusing on biomass production using by-products especially those from the agricultural sector (6). The purpose of this research work is to investigate Biomass yield (methane production) from Bambaranut straw, groundnut straw and milkweed.

\section{MATERIALS AND METHODS}

\section{A. Description of the Digester}

The digester component include the fermentation chamber (VF) the gas storage chamber (VGS) the gas collecting chamber (VC), the influent (VI) and the effluent chamber (VC) the components are shown diagrammatically in figure 1 below, the fermentation chamber is the chamber where the slurry charged in the digester is stored. The gas storage chamber is the upper frustum section of the digester; the gas collecting chamber is the chamber through which the stored gas exists from the digester to the gas collector through the loose or connecting pipes. The influent chamber channel through which the digester is charged while the digested slurry is discharged from the effluent chamber. The digesters are link to the condense water tanks which are linked to the gas collectors with the connecting pipes.

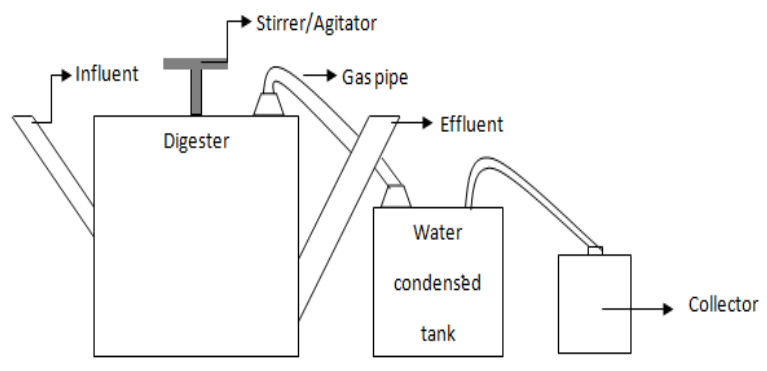

Fig 1: Digester

\section{B. Biogas procedures process:}

The subtract of ground nut straw, bambaranut straw as agriculture waste were obtained from Mbagbe Konshisha Local Government Area of Benue state while milk weed was gotten from North Bank Makurdi Local Government in Benue State. Nine (9) anaerobic size batch type digesters were constructed and used for this experiment. 30 liters volume digesters were used. Three replicates of $10 \%, 8 \%$ and $6 \%$ total solids (Ts) concentration each was digested for a retention time of 30 days. The gas yield (L/kgts) was measured from the $1^{\text {st }}$ day to the 30 th day of the digestion. The $\mathrm{pH}$ of the substrate was measured at an interval of 5days after loading. Temperature was measured using thermometer, the carbon /nitrogen ratio of the substrate was determined using proximate analysis before introducing it into the digesters.

\section{Determination of composition of substrate (Bambaranut, groundnut straw and Milkweed) through proximate analysis}

The moisture content was determined using the airoven method, crude protein was determined using Kjeldahl method, crude fat determined using Soxhlet solvent extraction method all as described by 7 alongside crude fibre and ash content while Carbohydrate was determined by difference as reported by 8 . Carbon content was determined using Walkely black method and the Nitrogen content was analyzed using regular macro-Kjekeldahl method

\section{Determination of $\mathbf{p H}$ Measurements}

$\mathrm{pH}$ measurement was carried out using a $\mathrm{pH}$ meter, the $\mathrm{pH}$ level of the substrate was measured before introducing it into the digester, and it was measured after 5 days interval during the retention time of 30 days.

\section{E. Determination of Gas Measurement}

The biogas produced from the digester in each case was collected in the gas collector and its volume determined using a graduated measuring cylinder.

\section{F. Determination of Total solids (TS) concentration.}

Total solid (TS) concentration was computed by weighing a stipulated gram of all the substrate after mixing from the digester. Each was kept in a peptic dish and weighed after which they were sun dried. Water content $\left(\mathrm{W}_{\mathrm{C}}\right)$ of the substrate sample was computed from Equation 1 while the TS concentration was calculated from equation 2

$$
\begin{aligned}
& \mathrm{W}_{\mathrm{C}}=\frac{\text { Initial weight }- \text { weight }}{\text { Initial weight }} \times 100 \% \quad 1 \\
& \mathrm{TS} \%=100-\mathrm{W}_{\mathrm{C}} \%
\end{aligned}
$$

\section{G. Temperature Determination}


A measured quantity of water was heated at a temperature of $25^{\circ} \mathrm{C}$ and mixed with the $10 \mathrm{~kg}$ substrate of each groundnut straw, bambaranut straw and milkweed, for the first replicates, the same heated quantity of water was mix with the $8 \mathrm{~kg}$ substrate of each groundnut straw, bambaranut straw and milkweed and the same measured water was heated at the same $25^{\circ} \mathrm{C}$ and mix with $6 \mathrm{~kg}$ substrate of each groundnut straw, bambaranut straw and milkweed. The subsequent temperatures were measured by tipping the thermometer head in the effluent of the digesters for daily readings of the temperature.

\section{RESULT AND DISCUSSION}

\section{A. Proximate Analysis of bambarnut straw, groundnut straw and milkweed}

The proximate analysis of the substrate as shown on table 1, showed that bambaranut straw has the highest moisture content of $7.87 \%$, which was followed by moisture content of groundnut straw with $6.88 \%$ and milkweed having the least moisture content of $6.57 \%$. The ash content ranged from $3.76 \%-4.22 \%$ with milkweed having the highest value and bambaranut having the least value. Crude fibre ranged from $20.87 \%-24.89 \%$ with groundnut straw having the highest value and bambaranut having the least value. Fatty content ranged from 2.88\%-5.98\% with groundnut having the highest value and milkweed straw having the least value. The protein content ranged from $5.2 \%-6.2 \%$ with groundnut having the highest value and milkweed having the least value. The carbohydrates content ranged from $51.97 \%$ $59.02 \%$ with milkweed having the highest value and groundnut having the least value (see figure 2).

Table 1: Proximate Analysis of Bambarnut Straw, Groundnut Straw and Milkweed

\begin{tabular}{lllllll}
\hline Parameter & $\begin{array}{l}\text { Moisture } \\
(\boldsymbol{\%})\end{array}$ & Ash (\%) & $\begin{array}{l}\text { Fibre } \\
(\boldsymbol{\%})\end{array}$ & $\begin{array}{l}\text { Fat } \\
(\boldsymbol{\%})\end{array}$ & $\begin{array}{l}\text { Protein } \\
(\boldsymbol{\%})\end{array}$ & $\begin{array}{l}\text { Carbohydrate } \\
(\boldsymbol{\%})\end{array}$ \\
\hline Milkweed & 6.57 & 4.22 & 22.11 & 2.88 & 5.2 & 59.02 \\
Groundnut Straw & 6.88 & 4.08 & 24.89 & 5.98 & 6.2 & 51.97 \\
Bambaranut Straw & 7.87 & 3.76 & 20.87 & 5.30 & 6.0 & 56.20 \\
\hline
\end{tabular}

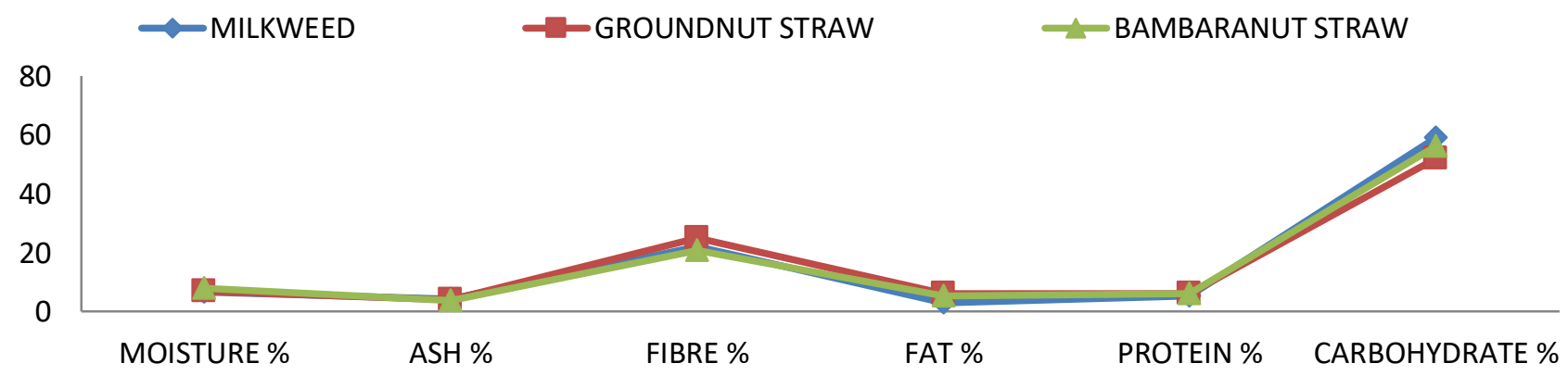

Fig 2: Composition trend of the different substrates

B. Discussion 
Table 2 shows the biogas yield (L/kgTS) for the batch digestion of slurries of $10 \mathrm{~kg}, 8 \mathrm{~kg}$ and $6 \mathrm{~kg}$ of total solid concentration from groundnut straw, bambaranut straw and milkweed substrates. The gas yield is of order $0.9480(\mathrm{~L} / \mathrm{kgTS})>0.6423(\mathrm{~L} / \mathrm{kgTS})$ $>0.4884(\mathrm{~L} / \mathrm{kgTS})$ quantity for groundnut straw, milkweed and bambaranut straw respectively.

ANOVA at $\mathrm{P}<0.05$ of the means of the gas produced for the different total solid showed that there was no significance difference in the gas yield of $10 \mathrm{~kg}$ and $8 \mathrm{~kg}$ slurries for the substrates but reveal a significance difference for the gas yield of $6 \mathrm{~kg}$ slurries, total daily yield of the gas and $\mathrm{pH}$ across the substrates. The values for the slurries of $10 \mathrm{~kg}, 8 \mathrm{~kg}$ and $6 \mathrm{~kg}$ total substrates for the period of gas yield are 6.6, 6.7 and 6.3 respectively. Implying that the slurries of higher total solid concentration has less acidic contents as compared to the lower total concentration of $6 \mathrm{~kg}$ which in return indicates the presence of methanogenic that activate the gas production (9). In the absence of any other reagent, $\mathrm{pH}$ alone is an important factor in checking gas yield through an anaerobically batch digester system, gas production is highest when the $\mathrm{pH}$ is between 6.7 and 7.2 and beyond this, $\mathrm{pH}$ limit digestion can proceed but with less efficiency (4).

Further analysis using the Duncans New Multiple Range Test (at $\mathrm{P}<0.05$ ) of the means of the gas yield for the different total solid concentrations showed that there is no significant difference between slurries of $10 \mathrm{~kg}$ and $8 \mathrm{~kg}$ total solid concentration of the substrates while a significant difference was recorded in the $6 \mathrm{~kg}$ total solid substrates and this could be a result of low acidic content in $\mathrm{pH}$ value that pave way for the micro bacteria to act on the slurries to aid gas product (10).

Table 2: Biogas yield from substrates

\begin{tabular}{|c|c|c|c|c|c|c|c|c|c|}
\hline \multirow[t]{2}{*}{ Substrate } & \multirow{2}{*}{\multicolumn{2}{|c|}{$\begin{array}{l}\text { Days of } \\
\text { Detention }\end{array}$}} & \multirow{2}{*}{\multicolumn{2}{|c|}{$\begin{array}{l}\text { Temperature } \\
\text { Range }\left({ }^{\circ} \mathrm{C}\right)\end{array}$}} & \multicolumn{3}{|c|}{ Substrate Weight } & \multirow{2}{*}{$\begin{array}{l}\text { Total } \\
\text { Quantity } \\
\text { Produced }\end{array}$} & \multirow[t]{2}{*}{ pH V. } \\
\hline & & & & & $10 \mathrm{~kg}$ & $8 \mathrm{~kg}$ & $6 \mathrm{~kg}$ & & \\
\hline \multirow[t]{2}{*}{ Milk weed } & \multirow[t]{2}{*}{26} & & \multicolumn{2}{|c|}{$23-38$} & $0.2961 \mathrm{a}$ & $0.1865 \mathrm{a}$ & $0.1596 \mathrm{a}$ & $0.6423 \mathrm{ab}$ & \multirow{2}{*}{$\begin{array}{l}6.6 \mathrm{a} \\
(.37)\end{array}$} \\
\hline & & & & & $(0.25)$ & $(0.21)$ & $(0.18)$ & $(.56)$ & \\
\hline Groundnut & \multirow[t]{2}{*}{26} & & \multicolumn{2}{|c|}{ 23-38 } & $0.2212 \mathrm{a}$ & $0.2654 \mathrm{a}$ & $0.4615 \mathrm{a}$ & $0.9480 \mathrm{a}$ & $6.7 \mathrm{a}$ \\
\hline Straw & & & & & $(0.25)$ & $(0.21)$ & $(0.67)$ & $(.80)$ & $(.55)$ \\
\hline Banbaranut & \multirow[t]{2}{*}{26} & & \multicolumn{2}{|c|}{ 23-38 } & $0.2577 \mathrm{a}$ & $0.1673 \mathrm{a}$ & $0.0635 \mathrm{a}$ & $0.4884 \mathrm{~b}$ & $6.3 b$ \\
\hline Straw & & & & & $(0.23)$ & $(0.17)$ & $(0.12)$ & $(.43)$ & (.74) \\
\hline \multicolumn{10}{|c|}{$\begin{array}{l}\text { Different letters along columns indicate significant difference of means according to Duncan Multiple Ran } \\
\text { Test }(\mathbf{P} \leq \mathbf{0 . 0 5})\end{array}$} \\
\hline \multicolumn{10}{|c|}{ Table 3: ANOVA } \\
\hline \multicolumn{4}{|c|}{ Source of Variation } & \multicolumn{2}{|c|}{ Sum of Squares } & $\mathrm{M}$ & Mean Square & $\mathrm{F}$ & Sig. \\
\hline \multirow[t]{3}{*}{ Biogas (10kg) } & \multicolumn{3}{|c|}{ Substrate } & 0.073 & \multicolumn{2}{|r|}{2} & 0.037 & 0.619 & $0.541^{\mathrm{NS}}$ \\
\hline & \multicolumn{3}{|c|}{ Error } & 4.429 & \multicolumn{2}{|c|}{75} & 0.059 & & \\
\hline & \multicolumn{3}{|c|}{ Total } & 4.502 & & 77 & & & \\
\hline Biogas (8kg) & & & rate & 0.140 & & 2 & 0.070 & 1.857 & $0.163^{\mathrm{NS}}$ \\
\hline & & $\mathrm{En}$ & & 2.836 & & 75 & 0.038 & & \\
\hline & & To & & 2.977 & & 77 & & & \\
\hline Biogas $(6 \mathrm{~kg})$ & & & rate & 2.116 & & 2 & 1.058 & 6.430 & $0.003 *$ \\
\hline
\end{tabular}


International Journal of Engineering Applied Sciences and Technology, 2020

Vol. 4, Issue 9, ISSN No. 2455-2143, Pages 329-334

Published Online January 2020 in IJEAST (http://www.ijeast.com)

\begin{tabular}{lllcccc}
\hline & Error & 12.339 & 75 & 0.165 & & \\
Daily Total & Total & 14.454 & 77 & & & \\
& Substrate & 2.846 & 2 & 1.423 & 3.724 & $0.029^{*}$ \\
& Error & 28.662 & 75 & 0.382 & & \\
PH & Total & 31.509 & 77 & & & \\
& Substrate & 2.846 & 2 & 1.423 & 4.350 & $0.016^{*}$ \\
& Error & 24.538 & 75 & 0.327 & & \\
\hline
\end{tabular}

Note: NS represent no significant difference while * represent significant difference @ $\mathrm{P} \leq 0.05$

Milkweed at 26 detention days with temperature range of $23^{\circ} \mathrm{C}-38^{\circ} \mathrm{C}$, revealed gas produced at $10 \mathrm{~kg}$ was 0.2961 and last $6 \mathrm{~kg}$, gas yield was 0.1596 with standard deviation of 0.18 . The total quantity of gas produced was 0.6423 at $\mathrm{pH}$ value of 6.6. Groundnut substrate at 26 detention days with temperature range of $23-38^{\circ} \mathrm{C}$ was able to produce gas at $10 \mathrm{~kg} 0.22129$ standard deviation of $0.25,8 \mathrm{~kg}$ produced 0.2654 while $6 \mathrm{~kg}$ produced gas of 0.4615 with 0.21 and 0.67 as standard deviation respectively with $\mathrm{pH}$ value of 6.7 , the total quantity produced was 0.9480 . Bambaranut substrate in 26 days detention period produced gas to 0.2577 at $10 \mathrm{~kg}, 0.1673$ at $8 \mathrm{~kg}$ and 0.0635 with standard deviation of $0.23,0.17$ and 0.12 respectively; the total quantity produced was 0.4884 at $\mathrm{pH}$ value of 6.3 .

Gas use for domestic purpose comprises of all living plant matter as well as organic wastes derived from human, animal and plants wastes, garbage. Sewage and trees are few examples of biomass. The result from the study revealed that, bambaranut straw, the highest gas yield was observed to be $0.3 \mathrm{ml}$ at a temperature range of $27^{\circ} \mathrm{C}-34^{\circ} \mathrm{C}$ at a load rate of $10 \mathrm{~kg}$, this implies that the higher the load rate of bambaranut straw, the higher the gas production, this result agrees with the work of 11 who pointed out that, some substrates gas yield is dependent upon the loading rate of the substrate, and the least gas yield from bambaranut was $0.00 \mathrm{ml}$ which was observed on the $6 \mathrm{~kg}$ of the substrate at temperature range of $28^{\circ} \mathrm{C}-37^{\circ} \mathrm{C}$ with a pH level of 6.0 thus implying that the $\mathrm{pH}$ level of the substrates affects its gas production as also stated by $\mathbf{9}$ and $\mathbf{1 2}$ who noted that the normal $\mathrm{pH}$ for a working biogas plant and for optimum production is between 6.7-7.0 hence the reason for poor gas production.

In terms of groundnut straw, the highest gas yield $(0.5 \mathrm{ml})$ was observed on the $10 \mathrm{~kg}$ and $8 \mathrm{~kg}$ load rate at a temperature range of $28{ }^{\circ} \mathrm{C}-37^{\circ} \mathrm{C}$ and at same high temperature of $27{ }^{\circ} \mathrm{C}-36{ }^{\circ} \mathrm{C}$ and same load rate of $10 \mathrm{~kg}$ and $8 \mathrm{~kg}$ yielded the same $0.5 \mathrm{ml}$ thus implying that high load rate and high temperature promotes high gas yield in groundnut straw, as this is confirmed by the work of 4 who opined that the rate of methane production has been found to be sustainably higher at thermophilic temperature compared to standard mesophilic temperature and the lowest gas yield from groundnut straw was observed on $6 \mathrm{~kg}$ load rate and at a temperature of $25^{\circ} \mathrm{C}$.

For milkweed, the highest gas yield of $1.2 \mathrm{ml}$ was observed on the $10 \mathrm{~kg}$ load rate of the substrate at a temperature range of $29^{\circ} \mathrm{C}-37^{\circ} \mathrm{C}$ and the lowest gas yield of $0.1 \mathrm{ml}$ at a load rate of $6 \mathrm{~kg}$ and at a temperature of $25^{\circ} \mathrm{C}$, this result also confirms the report of (4).

\section{CONCLUSION}

It can be concluded from the results obtained that; Biogas (methane) yield increases with increase in number of detention period till final decomposition is reached, Biogas yield for the various agricultural waste types is in the order of bambaranut straw substrate > groundnut substrate $>$ milkweed plant and Biogas yield increases with $\mathrm{pH}$ value of $6.7-7.0$

\section{Acknowledgement}

We sincerely appreciate the department of Agricultural and Environmental Engineering, University of Agriculture, Makurdi for sponsoring this research.

\section{REFERENCES}

1. Chynoweth, D. P. \& Isaacson, H. R.eds. (1987), Anaerobic Digestion of Biomass. Elsevier Applied Science Publishers Ltd, New York. (Pp 36- 48)

2. Ahn, Y.H., Song, Y.J., Lee, Y.J. and Park, S. (2002). Physicochemical characterization of UASB sludge with different size distributions. Environ. Technol. 23, (pp889-897).

3. Deublein, D. and Steinhauser, A. (2008). Biogas from Waste and Renewable Resources. An Introduction. Ed Wiley-VCH. Germany.

4. Isaacson, R. (1991). Methane from community waste, Elservier Applied science London and New York. 


\section{International Journal of Engineering Applied Sciences and Technology, 2020 Vol. 4, Issue 9, ISSN No. 2455-2143, Pages 329-334 \\ Published Online January 2020 in IJEAST (http://www.ijeast.com)}

5. Chynoweth, D. P. (1992) "Global Significance of iomethaneogenesis" in Global Environmental Chemistry, in Dunnetter, D. and O' Brian, eds., ACS Symposium Series, (pp338-351).

6. Itodo, I.N and J.O. Awulu (2001). Comparative Analysis of Biogas Yield from Poultry, Cattle and Piggery Wastes. African journal of Environmental Studies Vol. 2, No. 1: (pp152 154).

7. AOAC (2005). Official method of Analysis. 18th Edition, Association of Officiating Analytical Chemists, Washington DC, Method 935.14 and 992.24

8. Ihekoronye, A. I. and Ngoddy, P.O. (1985). Integrated food Science and technolgy for the tropics. Macmillan Publishers Ltd., London and Basingstoke, (pp 137-138).
9. Fulford, D. (1998). Running a biogas programme. A handbook intermediate technology publications, (pp103-105), South Hampton Row, London. WUB 4HH UK.

10. Scragg, A. (1988). Bio- technology for Engineering Biological systems in technological process. Ellis Horwood, Ltd. Publishers, Chichester, England.

11. Jay N. Meegoda, Brian Li, Kush Patel, and Lily B. Wang (2018). A Review of the Processes, Parameters, and Optimization of Anaerobic Digestion. Int. j. environ. Res. Public health, 2018 oct; 15(10). pp2224.

12. Kaparaju, P., Buendia, I., Ellegaard, L. and ngelidakia I. (2007). Effects of mixing on methane production during thermophilic anaerobic digestion of manure: Lab scale and pilot scale studies. Bioresour. Technol. 99, (pp4919-4928). 